\section{International Scientific Journal Theoretical \& Applied Science}

p-ISSN: 2308-4944 (print) e-ISSN: 2409-0085 (online)

Year: 2017 Issue: 03 Volume: 47

Published: 30.03.2017 http://T-Science.org

\section{F. B. Ibragimova}

Candidate of Technical Sciences, Researcher of Bukhara State University, Uzbekistan, Tashkent city original0010@mail.ru

(99890)7150466

SECTION 9. Chemistry and chemical technology.

\title{
A STUDY ON THE EFFECTS OF TEMPERATURE, TIME FLUSHING AND COMPOSITION OF PRINTING PAINT ON THE THICKENER WASHING-OFF
}

Abstract: Developed polymer composition consisting of starch, CMC and sericine as a thickener has the characteristics of the highest washability. At a temperature that equals to 800C, for 40 minutes washing circuit about $75 \%$ of thickener formulations of polymeric composition are removed from the fabric, in case of the conventional starch thickener only $10 \%$ of thickener formulations are removed.

Key words: Polymer composition, a thickener, washing, washability characteristics of thickener, he degree of removing, the dye.

Language: English

Citation: Ibragimova FB (2017) A STUDY ON THE EFFECTS OF TEMPERATURE, TIME FLUSHING AND COMPOSITION OF PRINTING PAINT ON THE THICKENER WASHING-OFF. ISJ Theoretical \& Applied Science, 03 (47): 174-177.

Soi: http://s-o-i.org/1.1/TAS-03-47-26 Doi: crossef https://dx.doi.org/10.15863/TAS.2017.03.47.26

\section{INTRODUCTION}

In this research paper, several factors such as the temperature, time flushing and composition of printing dye and their effects on thickener wash ability and ink compositions were studied.
Table 1 shows the thickener compositions and printing dyes investigating in printing cotton material in a laboratory setting with engraved print shaft [1]

Thickener compositions and printing dyes.

Table 1

\begin{tabular}{|l|l|l|l|}
\hline $\begin{array}{l}\text { № } \\
\mathrm{p} / \mathrm{n}\end{array}$ & Thickener & $\begin{array}{l}\text { № } \\
\mathrm{p} / \mathrm{n}\end{array}$ & Printing dyes (ink) \\
\hline 1 & Thickener consisting of simple starch & 4 & Thickener 1, 2, 3 with active dye \\
\hline 2 & $\begin{array}{l}\text { Polymer composed thickener consisting of } \\
\text { starch and CMC }\end{array}$ & 5 & Components of printing ink without dye \\
\hline 3 & $\begin{array}{l}\text { Thickener on the base of polymer } \\
\text { composition, consisting of CMC and sericine }\end{array}$ & 6 & Components of printing ink with active dye \\
\hline
\end{tabular}
\section{STUDY}

\section{MATERIALS AND METHODS IN THE}

Two coloring agents have been selected for the study, they are: monochlorotriazine bright purple $4 \mathrm{~K}$ and dichlortriazine bright-red 5CK. After printing and drying the samples have steamed. Flushing process was carried out on a laboratory model setting, which is considered to be a unit of aggregate, where the sample was directed to the expanded state. The machine does not allow water removability.
The dependence of thickener removal of the water temperature and the washing time at constant movement speed $-60 \mathrm{~m} / \mathrm{min}$ was studied [2]

According to data presented in Figure 1, a conventional thickener and modified starches washed away approximately in 40 minutes at $500 \mathrm{C}$, which corresponds to the curves I, I ', I " , in Figure $1 \mathrm{a}, \mathrm{b}$, c. The degree of cleansing consists of $24-27 \%$ from initial amount. However, as the curve I '" in picture $1(\mathrm{~g})$ reveals the thickener of manutex is removed better, at $34 \%$. 


\begin{tabular}{|c|c|c|c|c|c|c|}
\hline Impact Factor: & $\begin{array}{l}\text { ISRA (India) } \\
\text { ISI (Dubai, UAE } \\
\text { GIF (Australia) } \\
\text { JIF }\end{array}$ & $\begin{array}{l}=1.344 \\
=0.829 \\
=0.564 \\
=1.500\end{array}$ & $\begin{array}{l}\text { SIS (USA) } \\
\text { PИНЦ (Russia) } \\
\text { ESJI (KZ) } \\
\text { SJIF (Morocco) }\end{array}$ & $\begin{array}{l}=0.912 \\
=0.234 \\
=1.042 \\
=2.031\end{array}$ & $\begin{array}{l}\text { ICV (Poland) } \\
\text { PIF (India) } \\
\text { IBI (India) }\end{array}$ & $\begin{array}{l}=6.630 \\
=1.940 \\
=4.260\end{array}$ \\
\hline
\end{tabular}

Temperature rise of washing tub has a weaker effect on manutex RC removal compared to starch thickeners as shown in Figure $2(\mathrm{~g})$, the curve I "'

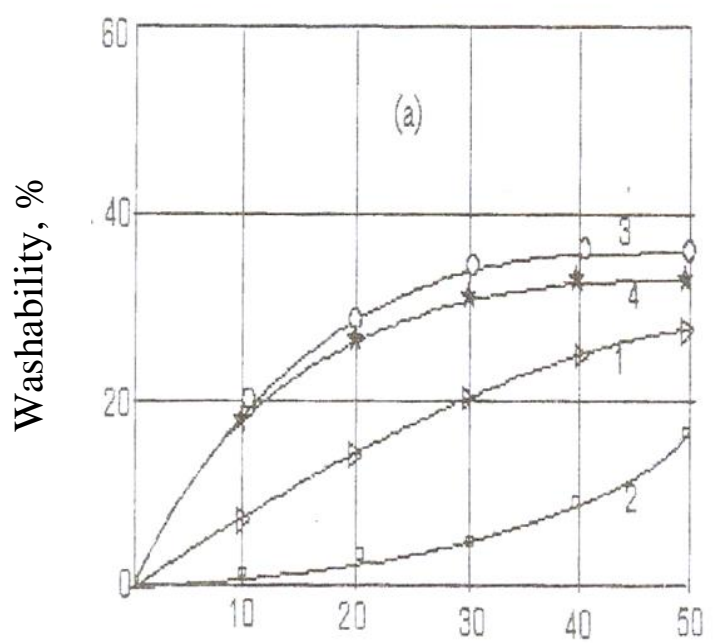

Washing time, minute

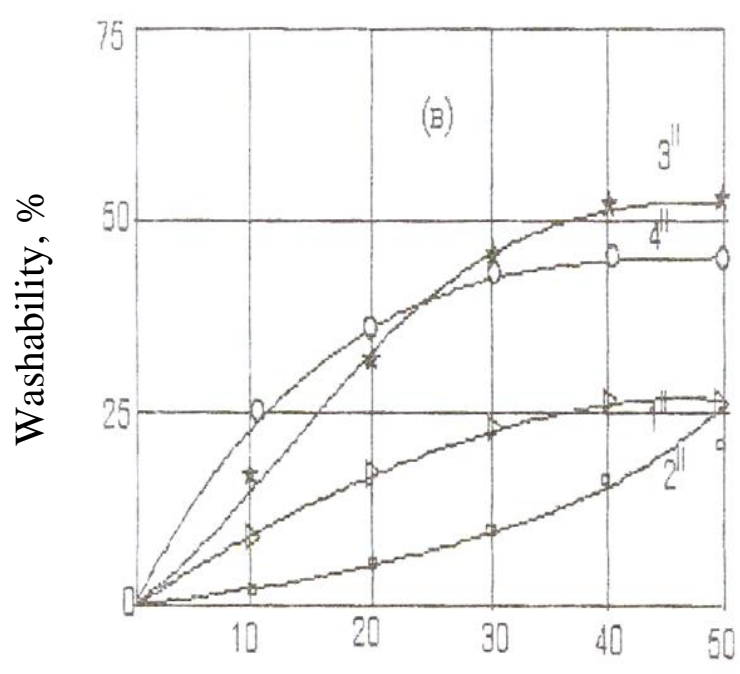

Washing time, minute

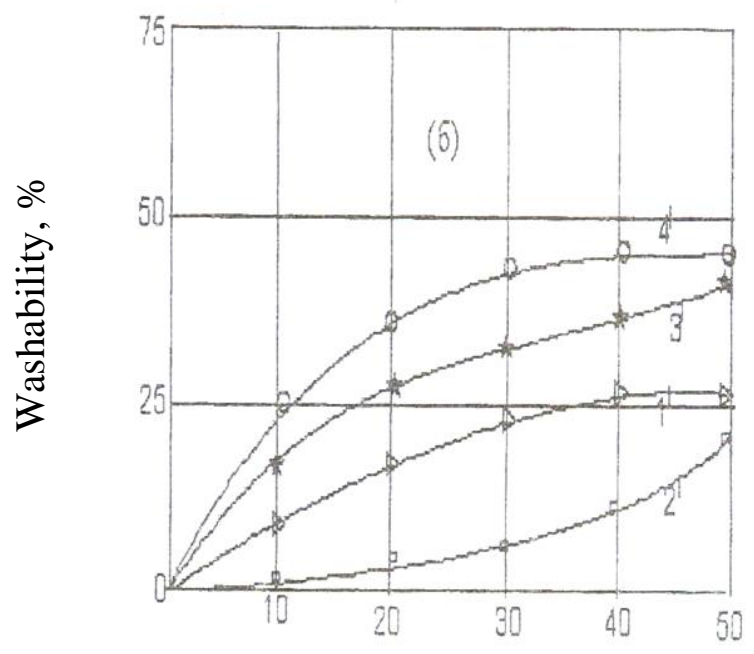

Washing time, minute

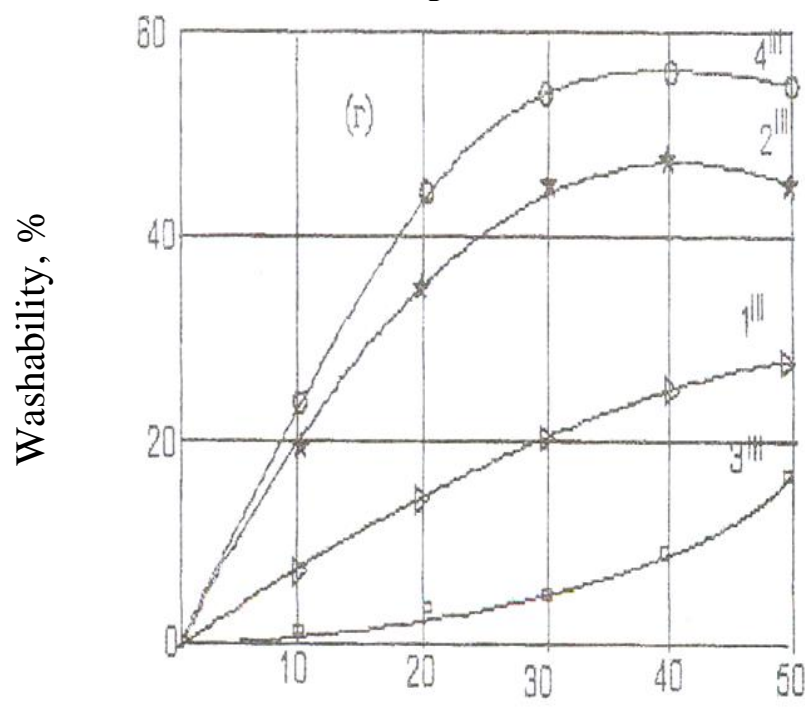

Washing time, minute

Picture 1. The Kinetics washability of various printed compositions at $500{ }^{\circ} \mathrm{C}, \mathrm{I}, \mathrm{I}$ ', I ", I '" - a thickener; 2 , $2^{\prime}, 2^{\prime}, 2^{\prime \prime \prime}$ - thickener with dye; $3,3^{\prime}, 3^{\prime \prime}, 3^{\prime \prime \prime}$-printing paint without pigment; 4, 4 ', 4 ', 4 '"' - printing ink dye; a-native starch; $b, \mathrm{v}$ - polymer composition; $\mathrm{g}$ - manutex.

However, taking into account the rigidity of washed samples it is possible to make a conclusion that even with a small degree of the stiffness of washed samples, which are printed manutexRS thickeners, are significantly less in toughness rather than the samples printed with starch thickeners. Apparently, the film of manutex is less in stiffness.
The presence of the dye in the thickener causes a nucleation of printed structure, due to the reactivity of active dyes which form a covalent chemical bond with the hydroxyl groups of the starch and reduces the degree of thickeners removal from the tissue that does not occur in the case of manutex thickener as shown in curve 2 "' , picture $(\mathrm{g})$ 


\begin{tabular}{l|lrl|l|ll} 
& ISRA (India) & $=\mathbf{1 . 3 4 4}$ & SIS (USA) & $=\mathbf{0 . 9 1 2}$ & ICV (Poland) & $\mathbf{6 . 6 3 0}$ \\
Impact Factor: & ISI (Dubai, UAE) & $\mathbf{0 . 8 2 9}$ & PUHЦ (Russia) & $=\mathbf{0 . 2 3 4}$ & PIF (India) & $=\mathbf{1 . 9 4 0}$ \\
& GIF (Australia) & $\mathbf{0 . 5 6 4}$ & ESJI (KZ) & $=\mathbf{1 . 0 4 2}$ & IBI (India) & $=\mathbf{4 . 2 6 0}$ \\
& JIF & $\mathbf{1 . 5 0 0}$ & SJIF (Morocco) & $\mathbf{2 . 0 3 1}$ & & \\
\hline
\end{tabular}

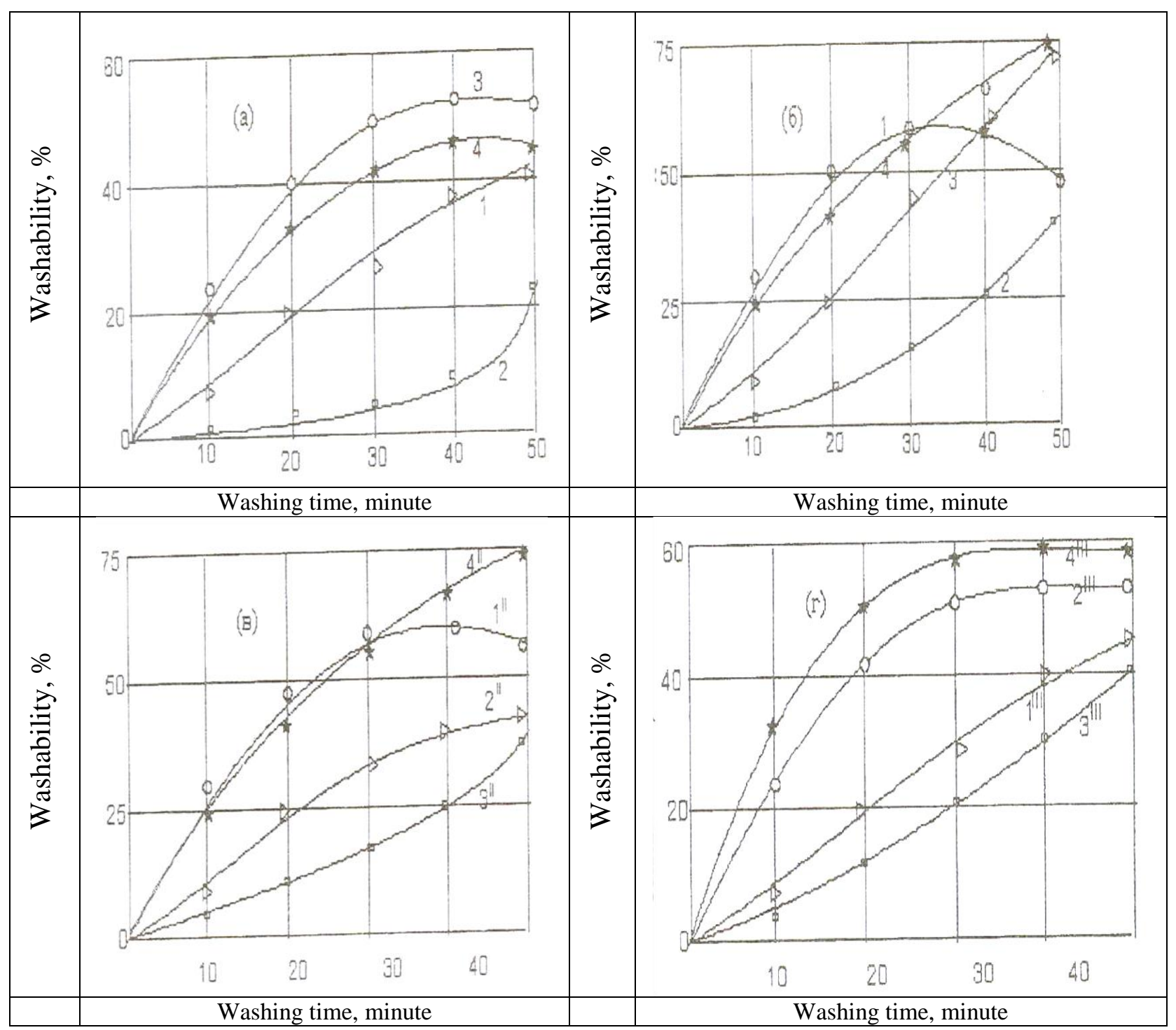

Picture 2. The Kinethics of various printed compositions at $80^{\circ} \mathrm{C}, I_{,} I^{\prime}, I^{\prime \prime}, I^{\prime \prime \prime}-$ a thickener; 2, 2', 2", 2'"'- a thisckener with dye; 3, 3', 3', $3^{\prime \prime \prime}$-printing paint without pigment; 4, 4', 4', $4^{\prime \prime \prime}$ - printing ink with dye; anative starch; б,B- polymer composition; $\Gamma-$ manutex.

Degree of thickener removal increases significantly through adding urea and alkalic agent to the printing composition. Apparently, the washabilty of thickener gets better, comparing to the both cases0 with printing composition without dye and full composition of printing ink.

It is clear that urea, which provides the inturgescence of thickener pellicle, provides better removal of thickener.

Coloring agent and other components of printed ink effect approximately equally on the removal of thickener from the material in washing process, at $50^{\circ} \mathrm{C}$. According to data presented in picture $1(\mathrm{~g})$, the curve $3^{\prime \prime \prime}$ and $4^{\prime \prime \prime}$, the washability of thickener stands at $37-53 \%$. In case with starch thickener, the addition of dyes decreases the washability of thickeners dramatically, whereas, the addition of urea and alkali agent rises this figure up to $6-21 \%$ for usual starch thickener that has been shown in the curves 3,4 , picture 2 ; and $18-25 \%$ for the thickener of polymer composition appropriately to the curves $3^{\prime}, 4^{\prime}, 3^{\prime \prime}$ and $4^{\prime \prime}$, picture $1(\mathrm{a}, \mathrm{b})$, at $50^{\circ} \mathrm{C}$ temperature of washing tub in the interval of 40 minutes.

The same results can be observed in the usage of fully composed printing dye. At the temperature of $80^{\circ} \mathrm{C}$ with 40 minutes time interval, the washing process removes printed compositions with the thickeners from polymer compositions at about $75 \%$ as it was clearly stated in the picture 2 (b), the curves $3^{\prime}, 3^{\prime \prime}, 4^{\prime}$; and in case of simple starch thickener only $10 \%$ of the mass is removed. 


\begin{tabular}{l|lr|ll|ll} 
& ISRA (India) & $=\mathbf{1 . 3 4 4}$ & SIS (USA) & $=\mathbf{0 . 9 1 2}$ & ICV (Poland) & $=\mathbf{6 . 6 3 0}$ \\
Impact Factor: & ISI (Dubai, UAE) $=\mathbf{0 . 8 2 9}$ & PUHIL (Russia) $=\mathbf{0 . 2 3 4}$ & PIF (India) & $=\mathbf{1 . 9 4 0}$ \\
& GIF (Australia) & $\mathbf{0 . 5 6 4}$ & ESJI (KZ) & $=\mathbf{1 . 0 4 2}$ & IBI (India) & $\mathbf{= 4 . 2 6 0}$ \\
& JIF & $=\mathbf{1 . 5 0 0}$ & SJIF (Morocco) & $=\mathbf{2 . 0 3 1}$ & & \\
\hline
\end{tabular}

\section{CONCLUSION}

In conclusion, water-miscible polymer composition can be removed easier and fully compared to ordinary starch consistency. What is more, the highest degree of washability belongs to the polymer composition consisting of starch, CMC, and sericine.

\section{References:}

1. Amonov MR, Ikhtiyarova GA, Yaryev OM (2004) Study of the color characteristics of printed cotton fabrics using a polymer composition // Plastic masses, 2004. №2. -p. 43-44.

2. Ikhtiyarova GA, Amonov MR, Yariev OM (2004) Evaluation of the structural and mechanical properties of the clot of printed fabrics with polymer compositions // Plastic masses, 2004. No.2.-p. 44-45.

3. Ikhtiyarova GA, Amonov MR, Yariev OM (2004) Investigation of rheological properties of a thickener based on the developed polymer composition // Composite materials. 2004 - №4. -p.27-29.

4. Ibragimova FB, Amanov MR, Sodikova SS (2001) A polymer composition based on the interaction of a, g-dichlorohydrin-glycerol with polyphosphoric acid and its application. M. Zh / Journal. Plastic masses. 2001., No.4., p. 42-44.

5. Ibragimova FB, Amanov MR, Yaryev OM (2001) Thermodynamic aspects of the formation of potassium polyphosphate and the polycondensation reaction based on it with dichlorohydrin-glycerol. M.: // Journal. Plastic masses. 2001. № 4, p. 37.
6. Ibragimova FB, Amonov MR, Ikhtiyorova GA (2002) Evaluation of the influence of the affinity of the composition of a thickener on the yield point and the fixation of printing ink. // Plastic masses. -M., 2002.-No.10. -p. 42.

7. Amonov MR (2002) Optimization of the composition of the composition for the thickening of the tissue. // Plastic masses. -M., 2002.-№9. -p. 44-45.

8. Amonov MR, Ikhtiyarova GA, Yaryev OM (2003) The use of polymer compositions as a thickener for printing paints. // Plastic masses. M., 2003. -No.7. -p. 48.

9. Melnikov BN, Zakharova TD, Kirillova MN (1982) Physical and chemical foundations of finishing manufacturing processes. -M.: Light and food industry, 1982. -p. 281.

10. Glubish PA (1975) The use of polymers of acrylic acid and its derivatives in the textile and light industries. -M.: Light industry, 1975.-205 p.

11. Amonov MR, Ikhtiyarova GA, Yariyev OM, Ravshanov KA (2002) Blisters based on natural and synthetic polymer compositions for printing fabrics //Uzbek Chemical Journal. 2002. - №4. p.71-77. 